\title{
NDVH or TAH- Choosing Wisely and Making Safely
}

Dr. Rabea Khatun ${ }^{1 *}$, Dr. Sohelee Nargis ${ }^{2}$, Dr. Mir Rabaya Akter ${ }^{3}$, Dr. Mohammad Azizur Rahman ${ }^{4}$

${ }^{1,2}$ Assistant Professor, Obs and Gynae, Kumudini Women's Medical College and Hospital, Mirzapur, Bangladesh

${ }^{3}$ Assistant Professor, Dept. of Endocrinology, President Abdul Hamid Medical College \& Hospital, Kishoreganj, Bangladesh

${ }^{4}$ Assistant Professor \&amp; Head, Physical Medicine and Rehabilitation, Mymensingh Medical College Hospital, Mymensingh, Bangladesh

DOI: $10.36347 /$ sjams.2020.v08i11.045

| Received: 29.10 .2020 | Accepted: 10.11.2020 | Published: 29.11.2020

*Corresponding author: Dr. Rabea Khatun

Abstract

Objective: In this study our main goal is to evaluate the efficiency and safety between Non-Descent Vaginal Hysterectomy (NDVH) and Total Abdominal Hysterectomy (TAH). Method: This randomized prospective comparative study was carried out Kumudini Women's Medical College from Jan2019 to Jan 2020. A total of 100 patients requiring hysterectomy were selected from the Outpatient Department and detailed history elicited and general and systemic examinations performed and confounding variables strictly controlled by following inclusion and exclusion criteria were enrolled for this study. Where in group A $(n=50)$ underwent vaginal hysterectomy (nondescent vaginal hysterectomy, NDVH) which was compared with group B $(n=50)$ who had abdominal hysterectomy. Results: During the study, in both group most of them were multiparas, followed by in NDVH group $8 \%$ had previous pelvic surgeries and $42 \%$ had medical illness where as in TAH group, $4 \%$ had previous pelvic surgeries and $40.5 \%$ had medical illness. In the vaginal group, $25 \%$ had undergone concurrent salpingo-ophorectomy whereas $30 \%$ in the abdominal group. The mean duration of surgery was 37.05 minutes in the vaginal group, whereas, it was 56.1 minutes in the abdominal group, implying a significant difference $(\mathrm{p}<0.05)$. Similarly, a significantly higher blood loss $(248$ $\mathrm{ml}$ ) was noted in the abdominal hysterectomy group, compared to $101.5 \mathrm{ml}$ in the vaginal group $(\mathrm{p}<0.05)$. Conclusion: From our study we can conclude that, patients requiring hysterectomy for benign non prolapse cases may be offered the option of vaginal hysterectomy which has quicker recovery, shorter hospitalization, lesser operative and postoperative morbidity compared to abdominal route.

Keywords: Non-Descent Vaginal Hysterectomy (NDVH), Total Abdominal Hysterectomy (TAH) , benign non prolapse.

Copyright (C) 2020 The Author(s): This is an open-access article distributed under the terms of the Creative Commons Attribution 4.0 International License (CC BY-NC 4.0) which permits unrestricted use, distribution, and reproduction in any medium for non-commercial use provided the original author and source are credited.

\section{INTRODUCTION}

Hysterectomy is the second most common operation performed by the Gynaecologists $[1,2]$, next only to Caesarean Section and can be done through abdominal, vaginal and laparoscopic routes [3]. Despite multiple studies stating that vaginal route is preferred to abdominal route in mobile uteri of 12 weeks or lesser, ACOG committee opinion is the only formal guideline establishing the fact $[4,5]$. Traditional abdominal and vaginal hysterectomies represent the most and least invasive techniques respectively. The ease and convenience offered by a large abdominal incision have led to the preponderance of abdominal hysterectomy over the vaginal route. Laparoscopic route is associated with increased operating times and rise in the rate of intraoperative injuries [6]. The common belief that bigger, bulky uteri, endometriosis, Pelvic inflammatory disease, previous surgeries[7], and narrow vagina make vaginal hysterectomy difficult to be performed are not considered to be contra-indications for non-descent vaginal hysterectomy and can be successfully attempted in all these conditions. It has a clear advantage over the abdominal route in obese women [8]. However, proper selection of patients is a critical factor in determining the success of vaginal procedures. In this study our main goal is to evaluate the efficiency and safety between Non-Descent Vaginal Hysterectomy (NDVH) and Total Abdominal Hysterectomy (TAH).

\section{OBJECTIVE}

To evaluate the efficiency and safety between Non-Descent Vaginal Hysterectomy (NDVH) and Total Abdominal Hysterectomy (TAH) 


\section{Methodology}

\begin{tabular}{|l|l|}
\hline Type of study & randomized prospective comparative study \\
\hline Place of study & Kumudini Women's Medical College \\
\hline Study period & Jan 2019 to Jan 2020 \\
\hline Study population & $\begin{array}{l}\text { A total of } 100 \text { patients requiring hysterectomy were selected from the Outpatient } \\
\text { Department and detailed history elicited and general and systemic examinations } \\
\text { performed and confounding variables strictly controlled by following inclusion and } \\
\text { exclusion criteria were enrolled for this study. Where in group A (n = 50) underwent } \\
\text { vaginal hysterectomy (non-descent vaginal hysterectomy, NDVH) which was compared } \\
\text { with group B }(\mathrm{n}=50) \text { who had abdominal hysterectomy. }\end{array}$ \\
\hline Sampling technique & Purposive \\
\hline
\end{tabular}

\section{METHOD}

During the study, Women were included in the study only if the uterine size was 12 weeks or lesser, uterus was mobile and if the operation was being performed for a benign uterine condition. Women were excluded if their uterus was more than 12 weeks size, restricted mobility, uterovaginal prolapse, complex adnexal mass, previous 2 or more LSCS. Women who had ophorectomy concurrently with hysterectomies were included. Informed, written consent was taken from all the patients after explaining the risks and benefits associated with the procedure. Approval of ethical committee was also taken.

\section{Data Analysis}

Statistical analysis was performed using the Statistical package for social science SPSS version 15.0. A descriptive analysis was performed for clinical features and results were presented as mean \pm standard deviation for quantitative variables and numbers (percentages) for qualitative variables.

In table-1 shows age distribution of the patients where in both group most of the patients belong to $21-30$ years age group, $82 \%$ and $80 \%$. The following table is given below in detail:

Table-1: Age distribution of the patients

\begin{tabular}{|c|c|c|}
\hline Age group & NDVH, Percent & TAH, percent \\
\hline$<32$ years & $8 \%$ & $5 \%$ \\
\hline $32-40$ years & $82 \%$ & $80 \%$ \\
\hline$>30$ years & $10 \%$ & $15 \%$ \\
\hline
\end{tabular}

In table- 2 shows residential area of the patients where $40 \%$ belong to rural area, where as $60 \%$ belongs to urban area. The following table is given below in detail:

Table-2: Residential area of the patients

\begin{tabular}{|c|c|}
\hline Residential area & $\%$ \\
\hline Rural & $60 \%$ \\
\hline Urban & $40 \%$ \\
\hline
\end{tabular}

In table-3 shows base line characteristics of the patients where in both group most of them were multiparas, followed by in NDVH group $8 \%$ had previous pelvic surgeries and $42 \%$ had medical illness where as in $\mathrm{TAH}$ group, $4 \%$ had previous pelvic surgeries and $40.5 \%$ had medical illness. The following table is given below in detail:

Table-3: Base line characteristics of the patients

\begin{tabular}{|l|c|c|}
\hline \multicolumn{1}{|c|}{ Parity } & $\begin{array}{c}\text { NDVH, } \\
\text { Percent }\end{array}$ & $\begin{array}{c}\text { TAH, } \\
\text { percent }\end{array}$ \\
\hline Nullipara & $30 \%$ & $40 \%$ \\
\hline Multiparas & $70 \%$ & $60 \%$ \\
\hline $\begin{array}{l}\text { Patients with previous } \\
\text { pelvic surgeries }\end{array}$ & $8 \%$ & $4 \%$ \\
\hline Medical illness & $42 \%$ & $40.5 \%$ \\
\hline
\end{tabular}

In table-4 shows Gynaecological disease of the patients where the Gynaecological diseases were diagnosed by pathological examination. The diseases in each group were comparable. The following table is given below in detail:

Table-4: Gynaecological disease of the patients

\begin{tabular}{|l|c|c|}
\hline \multicolumn{1}{|c|}{ DIAGNOSIS } & $\begin{array}{c}\text { NDVH, } \\
\text { Percent }\end{array}$ & $\begin{array}{c}\text { TAH, } \\
\text { percent }\end{array}$ \\
\hline Fibroid & $56 \%$ & $44 \%$ \\
\hline $\begin{array}{l}\text { Endometrial } \\
\text { hyperplasia/polyp }\end{array}$ & $21 \%$ & $23 \%$ \\
\hline Chronic cervicitis & $7 \%$ & $5 \%$ \\
\hline Adenomyosis & $8 \%$ & $9.5 \%$ \\
\hline $\begin{array}{l}\text { Dysfunctional Uterine } \\
\text { Bleeding }\end{array}$ & $6.1 \%$ & $4.9 \%$ \\
\hline $\begin{array}{l}\text { Cervical Intraepithelial } \\
\text { Neoplasia }\end{array}$ & $3 \%$ & $2 \%$ \\
\hline
\end{tabular}

In figure-1 shows distribution of the patients according to Salphingo-oophorectomy. In the vaginal group, $25 \%$ had undergone concurrent salpingoophorectomy whereas $30 \%$ in the abdominal group. The following figure is given below in detail: 


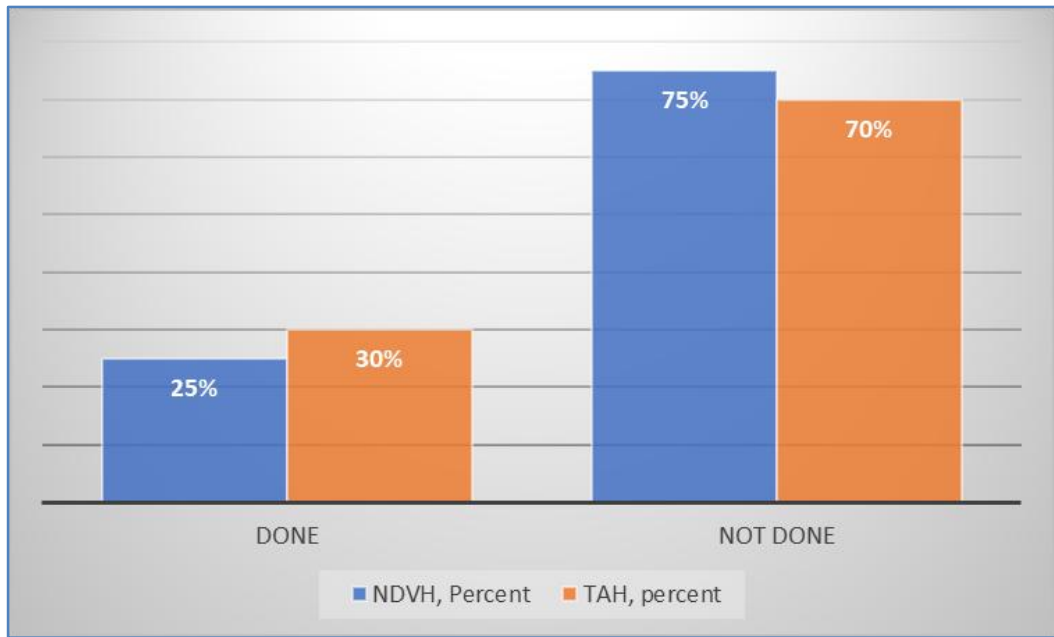

Fig-1: Distribution of the patients according to Salphingo-oophorectomy

In table-5 shows intraoperative and postoperative outcomes where the mean duration of surgery was 37.05 minutes in the vaginal group, whereas, it was 56.1 minutes in the abdominal group, implying a significant difference $(\mathrm{p}<0.05)$. Similarly, a significantly higher blood loss $(248 \mathrm{ml})$ was noted in the abdominal hysterectomy group, compared to 101.5 $\mathrm{ml}$ in the vaginal group ( $\mathrm{p}<0.05)$. The following table is given below in detail:

Table-5: Intraoperative and postoperative outcomes

\begin{tabular}{|c|c|c|c|c|c|}
\hline DIAGNOSIS & NDVH & TAH & $\begin{array}{c}\text { Test of } \\
\text { significance }\end{array}$ & p-value & $\begin{array}{c}\text { Statistical } \\
\text { significance }\end{array}$ \\
\hline Operation duration (mins) & 37.05 & 56.1 & t' test & $<0.00001$ & Significant \\
\hline Blood loss (ml) & 101.5 & 248 & & $<0.00001$ & Significant \\
\hline $\begin{array}{c}\text { Postoperative pain (days of analgesic } \\
\text { requirement) }\end{array}$ & 1.60 & 3.70 & & $<0.00001$ & Significant \\
\hline Hospital stay (days) & 5 & 11 & & \\
\hline Postoperative mobility (days) & 3 & 5 & & $<0.00001$ & Significant \\
\hline \begin{tabular}{c|c|c|c|} 
Postoperative blood transfusion (no. of \\
units)
\end{tabular} & $10 \%$ & $37 \%$ & \multirow{2}{*}{$\chi^{2}$ (chi-square test) } & $<0.00001$ & Significant \\
\hline Postoperative wound infection & $1 \%$ & $30 \%$ & & & Significant \\
\hline Febrile morbidity & $3 \%$ & $21 \%$ & & $<0.00001$ & Significant \\
\hline Postoperative systemic infections & $6 \%$ & $7 \%$ & & $<0.00001$ & Non-Significant \\
\hline
\end{tabular}

\section{DISCUSSION}

One study conducted on 80 women planned for NDVH had a success rate of $95 \%$ [8]. These patients were treated by vaginal hysterectomy and the operating time; laparotomy conversion rate and intraoperative blood loss was directly proportional to the size of the uterus and concluded that vaginal hysterectomy is a safe and effective procedure in uteri of less than 12 weeks size. Where as in our study, mean duration of surgery was 37.05 minutes in the vaginal group, whereas, it was 56.1 minutes in the abdominal group, implying a significant difference $(\mathrm{p}<0.05)$. Similarly, a significantly higher blood loss $(248 \mathrm{ml})$ was noted in the abdominal hysterectomy group, compared to 101.5 $\mathrm{ml}$ in the vaginal group $(\mathrm{p}<0.05)$.

Another study comparing vaginal hysterectomy with abdominal hysterectomy with 23 patients in each group and found a reduced operating time, lesser intraoperative blood loss, reduced postoperative morbidity and shorter hospital stay in the vaginal hysterectomy group [9]. Other article concluded experiment that intraoperative and postoperative morbidity were lesser in vaginal hysterectomy compared to abdominal hysterectomy and that vaginal hysterectomy should be the procedure of choice wherever possible[10]. Another study on 250 patients challenged the common contra-indications to vaginal hysterectomy including large uteri, nulliparas, previous CS or laparotomies and concluded that the abovementioned factors are rarely contra-indications [11]. Where as in our studyin both group most of them were multiparas, followed by in NDVH group $8 \%$ had previous pelvic surgeries and $42 \%$ had medical illness where as in TAH group, $4 \%$ had previous pelvic surgeries and $40.5 \%$ had medical illness.

\section{Conclusion}

From our study we can conclude that, patients requiring hysterectomy for benign non prolapse cases 
may be offered the option of vaginal hysterectomy which has quicker recovery, shorter hospitalization, lesser operative and postoperative morbidity compared to abdominal route.

\section{REFERENCES}

1. Bernstein SJ, McGlyn EA, Siu AL. The appropriateness of hysterectomy. A comparison of care in seven health plans. Health maintenance organization quality of care consortium. JAMA. 1993:269-2398.

2. Grave EJ, Gillum BS. 1994 Summary. National hospital discharge survey. Advance data from vital and health statistics No 278. National Center for Health Statistics, Hyattsville, Maryland; 1996.

3. West S, Drannov P. The hysterectomy Hoax. New York: Doubleday; 1994: 214.

4. ACOG Committee Opinion. Number 311, April 2005. Appropriate use of laparoscopically assisted vaginal hysterectomy. Obstet Gynecol. 2005; 105:929-30.
5. Richardson RE, Bournas N, Magos AL. Is laparoscopic hysterectomy a waste of time? Lancet. 1995; 345:36-41.

6. Coulam CB, Pratt JH. Vaginal hysterectomy: is previous pelvic operation a contraindication. Am J Obstet Gynecol. 1973; 116:252.

7. Pitkin RM. Vaginal hysterectomy in obese women. Obstet Gynecol. 1977; 49:567.

8. Pratt JH, Daikoku NH. Obesity and vaginal hysterectomy. J Reprod med. 1990; 35:945.

9. Umeora OUJ, Onoh RC, Eze JN, Igberase GO. Abdominal versus vaginal hysterectomy: Appraisal of indications and complications in a Nigerian Federal Medical Centre. Nep Journ OG. 2009;4(1):25-29.

10. Dicker RC, Scally MJ, Greenspan JR. Hysterectomy among women of reproductive agetrends in USA 1970 -78. JAMA. 1982; 248:32327.

11. Te Linde's Operative Gynaecology, Tenth Edition -Abdominal Hysterectom, 733-739. 